\title{
Kocuria aegyptia sp. nov., a novel actinobacterium isolated from a saline, alkaline desert soil in Egypt
}

Correspondence

Wen-Jun Li

wjli@ynu.edu.cn

\author{
Wen-Jun Li, ${ }^{1}$ Yu-Oin Zhang, ${ }^{1,4}$ Peter Schumann, ${ }^{2}$ Hua-Hong Chen, ${ }^{1}$ \\ Wael N. Hozzein, ${ }^{3}$ Xin-Peng Tian, ${ }^{1}$ Li-Hua $X u^{1}$ and Cheng-Lin Jiang ${ }^{1}$ \\ 'Laboratory for Conservation and Utilization of Bio-Resources, Yunnan Institute of Microbiology, \\ Yunnan University, Kunming, Yunnan, 650091, People's Republic of China
}

${ }^{2}$ DSMZ - Deutsche Sammlung von Mikroorganismen und Zellkulturen GmbH, Mascheroder Weg 1b, D-38124 Braunschweig, Germany

${ }^{3}$ Botany Department, Faculty of Science, Cairo University, Beni-Suef, Egypt

${ }^{4}$ Institute of Medicinal Biotechnology, Chinese Academy of Medical Sciences and Peking Union Medical College, Beijing, 100050, People's Republic of China

A coccoid, non-motile actinobacterium, designated strain $\mathrm{YIM} 70003^{\top}$, was isolated from a saline, alkaline, desert-soil sample from Egypt. Phylogenetic analysis based on 16S rRNA gene sequences revealed that the organism formed a distinct phyletic line within the genus Kocuria and was most closely related to Kocuria polaris DSM $14382^{\top}$ ( $98.6 \%$ sequence similarity) and Kocuria rosea DSM $20447^{\top}$ (98.2\%). Chemotaxonomic data, including the Lys-Ala 3 peptidoglycan type, the presence of phosphatidylglycerol and diphosphatidylglycerol as the predominant phospholipids, the presence of $\mathrm{MK}-8\left(\mathrm{H}_{2}\right)$ and $\mathrm{MK}-9\left(\mathrm{H}_{2}\right)$ as the major menaquinones, the predominance of fatty acids ai- $\mathrm{C}_{15 \text { : } 0}$ and $\mathrm{i}-\mathrm{C}_{15: 0}$ and the DNA G+C content, also supported the affiliation of the isolate to the genus Kocuria. The low DNA-DNA relatedness with $K$. polaris DSM $14382^{\top}(56 \cdot 6 \%)$ and $K$. rosea DSM $20447^{\top}(15.5 \%)$ in combination with phenotypic data show that strain YIM $70003^{\top}$ should be classified as a novel species of the genus Kocuria. The name Kocuria aegyptia sp. nov. is proposed, with strain YIM $70003^{\top}\left(=\mathrm{CCTCC} \mathrm{AA} 03006^{\top}=\mathrm{CIP} 107966^{\top}=\mathrm{KCTC}^{\circ}\right.$ $19010^{\top}=\mathrm{DSM} 17006^{\top}$ ) as the type strain.

The genus Kocuria was established by Stackebrandt et al. (1995) by taxonomic dissection of the genus Micrococcus, and was clearly separated from Micrococcus and Micrococcusrelated taxa on the basis of phylogenetic analyses using $16 \mathrm{~S}$ rRNA gene sequences. Members of Kocuria are Grampositive, aerobic, non-encapsulated, non-halophilic, nonendospore-forming cocci characterized by the presence of menaquinones $\mathrm{MK}-7\left(\mathrm{H}_{2}\right)$ and $\mathrm{MK}-8\left(\mathrm{H}_{2}\right)$, lysine-based peptidoglycan variation $\mathrm{A} 3 \alpha$, phosphatidylglycerol and diphosphatidylglycerol as the major phospholipids, a predominance of saturated branched fatty acids such as ai$\mathrm{C}_{15: 0}$ and a genomic DNA $\mathrm{G}+\mathrm{C}$ content in the range 60-75 mol\% (Stackebrandt et al., 1995; Boháček et al., 1969; Kloos et al., 1974; Kocur et al., 1971; Kovács et al., 1999; Reddy et al., 2003; Kim et al., 2004). At the time of writing, there are eight Kocuria species with validly published names: Kocuria kristinae, K. palustris, K. polaris, K. rhizophila, $K$. rosea, K. varians, K. marina and K. carniphila (Stackebrandt

Published online ahead of print on 2 December 2005 as DOI 10.1099/ ijs.0.63876-0.

The GenBank/EMBL/DDBJ accession number for the 16S rRNA gene sequence of strain $\mathrm{YIM} 70003^{\top}$ is D0059617. et al., 1995; Kovács et al., 1999; Reddy et al., 2003; Kim et al., 2004; Tvrzová et al., 2005). Of these species, only K. marina was isolated from a high-salinity environment (Kim et al., 2004). In this paper, we report a polyphasic taxonomic study of strain YIM $70003^{\mathrm{T}}$ isolated from a saline, alkaline, desert-soil sample collected in Egypt.

Strain YIM $70003^{\mathrm{T}}$ was isolated on modified Horikoshi agar medium (Horikoshi \& Grant, 1998) using the dilution plating method. This medium contained the following $\left(\mathrm{g} \mathrm{l}^{-1}\right)$ : glucose, $10 \cdot 0$; peptone, $5 \cdot 0$; yeast extract, $5 \cdot 0$; $\mathrm{KH}_{2} \mathrm{PO}_{4}, 1 \cdot 0 ; \mathrm{MgSO}_{4} .7 \mathrm{H}_{2} \mathrm{O}, 0 \cdot 2 ; \mathrm{Na}_{2} \mathrm{CO}_{3}, 10 \cdot 0$; and agar, $15 ; \mathrm{pH}, 10 \cdot 0-10 \cdot 5$. Sodium carbonate was sterilized separately and then added to the medium. $\mathrm{NaHCO}_{3} /$ $\mathrm{Na}_{2} \mathrm{CO}_{3}$ buffer was used to adjust the $\mathrm{pH}$. The purified strain was maintained on Horikoshi agar slants at $4{ }^{\circ} \mathrm{C}$ and as $20 \%(\mathrm{w} / \mathrm{v})$ glycerol suspensions at $-20{ }^{\circ} \mathrm{C}$. Biomass for chemical and molecular studies was obtained by cultivation using Horikoshi broth $\left(28^{\circ} \mathrm{C}, 1\right.$ week, 150 r.p.m.).

Gram staining was carried out by using the standard Gram reaction and was confirmed by using the $\mathrm{KOH}$ lysis test (Cerny, 1978). Morphology and motility were examined by using light microscopy (model $\mathrm{BH} 2$; Olympus) and 
Table 1. Differentiating characteristics of $K$. aegyptia YIM $70003^{\top}$ and other Kocuria species

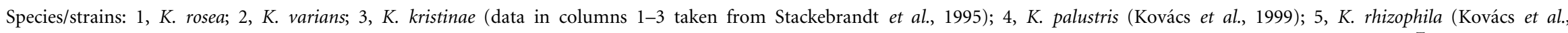

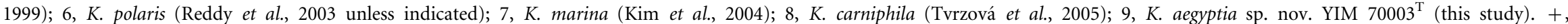
Positive; -, negative; v, variable; W, weak; ND, no data available. Data for all species except K. rosea, K. varians and K. kristinae are based on the type strains.

\begin{tabular}{|c|c|c|c|c|c|c|c|c|c|}
\hline Characteristic & 1 & 2 & 3 & 4 & 5 & 6 & 7 & 8 & 9 \\
\hline Pigment colour & Pink or red & Yellow & $\begin{array}{l}\text { Pale cream to } \\
\text { pale orange }\end{array}$ & Pale yellow & Yellow & Orange & Orange & Yellow & Pink \\
\hline Oxidase reaction & - & - & + & - & - & + & - & - & - \\
\hline Phosphatase & - & - & - & - & + & - & - & - & ND \\
\hline Nitrate reduction & + & + & - & + & - & + & + & + & - \\
\hline $\mathrm{H}_{2} \mathrm{~S}$ production & - & - & - & $\mathrm{W}$ & $\mathrm{W}$ & ND & - & ND & - \\
\hline \multicolumn{10}{|l|}{ Hydrolysis of: } \\
\hline Gelatin & - & $\mathrm{V}$ & - & - & + & $-{ }^{*}$ & + & - & - \\
\hline Starch & $\mathrm{V}$ & $\mathrm{V}$ & - & - & - & + & - & - & - \\
\hline Tween 80 & $\mathrm{~V}$ & - & - & - & + & $+^{*}$ & - & - & - \\
\hline Urea & - & + & $\mathrm{V}$ & + & - & - & + & - & - \\
\hline \multicolumn{10}{|l|}{ Growth at/in: } \\
\hline $37^{\circ} \mathrm{C}$ & + & + & + & - & + & - & + & + & + \\
\hline $0 \% \mathrm{NaCl}$ & + & + & + & + & + & + & + & + & - \\
\hline $5 \% \mathrm{NaCl}$ & + & + & + & + & + & - & + & + & + \\
\hline $7 \cdot 0 / 7 \cdot 5 \% \mathrm{NaCl}$ & + & + & + & + & + & - & + & + & - \\
\hline $10 \% \mathrm{NaCl}$ & - & + & + & - & + & - & + & $\mathrm{w}$ & - \\
\hline \multicolumn{10}{|l|}{ Chemotaxonomy } \\
\hline Major menaquinone(s) & MK-8 $\left(\mathrm{H}_{2}\right)$ & $\mathrm{MK}-7\left(\mathrm{H}_{2}\right)$ & $\begin{array}{l}\text { MK-7 }\left(\mathrm{H}_{2}\right), \\
\text { MK-8 }\left(\mathrm{H}_{2}\right)\end{array}$ & MK-7 $\left(\mathrm{H}_{2}\right)$ & $\begin{array}{l}\text { MK-7 }\left(\mathrm{H}_{2}\right), \\
\text { MK-8 }\left(\mathrm{H}_{2}\right)\end{array}$ & $\begin{array}{l}\text { MK-7 }\left(\mathrm{H}_{2}\right), \\
\text { MK-8 }\left(\mathrm{H}_{2}\right)\end{array}$ & $\mathrm{ND}$ & $\mathrm{MK}-7\left(\mathrm{H}_{2}\right)$ & $\begin{array}{l}\text { MK-8 }\left(\mathrm{H}_{2}\right), \\
\text { MK-9 }\left(\mathrm{H}_{2}\right)\end{array}$ \\
\hline Major fatty acid(s) & ai- $C_{15: 0}$ & ai- $C_{15: 0}$ & ai- $\mathrm{C}_{15: 0}$ & ai- $C_{15: 0}$ & ai- $C_{17: 0}$, ai- $C_{15: 0}, i-C_{15: 0}$ & ai- $C_{15: 0}$ & ai- $C_{15: 0}$ & ai- $C_{15: 0}$ & ai- $C_{15: 0}, i-C_{15: 0}$ \\
\hline DNA $\mathrm{G}+\mathrm{C}$ content $(\mathrm{mol} \%)$ & $66-75$ & $66-72$ & $67 \cdot 0$ & $69 \cdot 6$ & $69 \cdot 4$ & $72 \cdot 5$ & $60 \cdot 0$ & $71 \cdot 0$ & $73 \cdot 0$ \\
\hline
\end{tabular}

*Based on the report of Tvrzová et al. (2005). 
electron microscopy (JEM-1010; JEOL) with cells from exponentially growing cultures. Colony morphology was observed on Horikoshi medium after incubation at $28^{\circ} \mathrm{C}$ for 3 days. The colony colour was determined using ISCC-NBS colour charts (Kelly, 1964). Growth was tested in Horikoshi broth at $4,10,20,28,37,40,45$ and $55^{\circ} \mathrm{C}$. The $\mathrm{pH}$ growth range and optimum were investigated at $\mathrm{pH} 4 \cdot 0-13 \cdot 0$ using the buffer system described by Xu et al. (2005). Liquid cultures were cultivated in tubes at $28^{\circ} \mathrm{C}$ for $2-3$ weeks using ISP 2 as the basic medium. Growth at different concentrations $(0,1,3,7,10,15$ and $20 \%)$ of sodium, potassium, magnesium and calcium chlorides was tested, again in ISP 2 basic medium. Metabolic properties were determined using API ID 32E test kits (bioMérieux) according to the manufacturer's instructions. Other physiological and biochemical tests were performed as described previously (Gonzalez et al., 1978).

The cells of strain YIM $70003^{\mathrm{T}}$ were Gram-positive, aerobic, non-motile, non-endospore-forming, coccoid and about $0 \cdot 8-1 \cdot 1 \mu \mathrm{m}$ in diameter. The colonies were pink, circular, slightly convex, opaque and had a maximum diameter of about $2 \mathrm{~mm}$ after incubation at $28^{\circ} \mathrm{C}$ for $48 \mathrm{~h}$ on Horikoshi agar medium. No diffusible pigments were produced on any of the media. The isolate was catalase-positive and gave a negative oxidase reaction. Detailed physiological and biochemical properties are given in Table 1 and in the species description.

The chemotaxonomic properties, including peptidoglycan type, cell-wall sugars, phospholipids, menaquinones and whole-cell fatty acid pattern, were analysed as described previously (Li et al., 2004). Strain YIM $70003^{\mathrm{T}}$ possessed peptidoglycan type $\mathrm{Lys}-\mathrm{Ala}_{3}$, variation $\mathrm{A} 3 \alpha$. Galactose and minor amounts of glucose were detected in the purified cell wall. The phospholipids consisted of phosphatidylglycerol and diphosphatidylglycerol. The menaquinones were represented by MK- $8\left(\mathrm{H}_{2}\right)$, MK- $9\left(\mathrm{H}_{2}\right)$, MK- $7\left(\mathrm{H}_{2}\right)$, MK-6 $\left(\mathrm{H}_{2}\right)$ and MK-10 $\left(\mathrm{H}_{2}\right)(27: 8 \cdot 5: 2 \cdot 5: 1 \cdot 5: 1$, respectively). The major fatty acids were ai- $\mathrm{C}_{15: 0}(55 \cdot 3 \%)$ and $\mathrm{i}-\mathrm{C}_{15: 0}$ $(20 \cdot 4 \%)$.

Extraction of genomic DNA and PCR amplification of $16 \mathrm{~S}$ rRNA gene were performed as described by Xu et al. (2003). Multiple alignments with sequences of the most closely related actinobacteria and calculations of levels of sequence similarity were carried out using CLUSTAL X (Thompson et al., 1997). A phylogenetic tree was constructed using the neighbour-joining method of Saitou \& Nei (1987) from $K_{\text {nuc }}$ values (Kimura, 1980, 1983) by using MEGA version 2.1 (Kumar et al., 2001). The topology of the phylogenetic tree was evaluated by using the bootstrap resampling method of Felsenstein (1985) with 1000 replicates.

The almost-complete 16S rRNA gene sequence (1492 bp) for strain YIM $70003^{\mathrm{T}}$ was determined. Phylogenetic analysis revealed that the strain's closest relative were $K$. polaris DSM $14382^{\mathrm{T}}$ and $K$. rosea DSM $20447^{\mathrm{T}}$, showing respective 16S rRNA gene sequence similarities of $98 \cdot 6$ and $98 \cdot 2 \%$
(Fig. 1). The DNA G+C content was determined as $73.0 \mathrm{~mol} \%$ by using the thermal denaturation method of Marmur \& Doty (1962). DNA-DNA relatedness was studied using the optical renaturation method (De Ley et al., 1970; Huß et al., 1983; Jahnke, 1992) on a UV-Vis spectrophotometer (model UV1601; Shimadzu). The DNA-DNA hybridization values for strain YIM $70003^{\mathrm{T}}$ with respect to K. polaris DSM $14382^{\mathrm{T}}$ and K. rosea DSM $20447^{\mathrm{T}}$ were $56 \cdot 6$ and $15 \cdot 5 \%$, respectively.

The results of comparative 16S rRNA sequence analysis clearly demonstrate that strain YIM $70003^{\mathrm{T}}$ is a member of the genus Kocuria. The chemotaxonomic characteristics of strain YIM $70003^{\mathrm{T}}$, such as peptidoglycan type, major fatty acids and DNA G+C content, were consistent with its assignment to the genus Kocuria.

The DNA-DNA relatedness among strains YIM $70003^{\mathrm{T}}, K$. polaris DSM $14382^{\mathrm{T}}$ and K. rosea DSM $20447^{\mathrm{T}}$ is below $70 \%$, which indicates that the novel isolate represents a distinct genospecies (Wayne et al., 1987) of the genus Kocuria. The relatively large proportion of menaquinone MK- $9\left(\mathrm{H}_{2}\right)$ (21\%), the fatty acid profile and some other phenotypic properties (e.g. pigmentation, $\mathrm{NaCl}$ and temperature tolerance, oxidase reaction, nitrate reduction and hydrolysis results) of strain YIM $70003^{\mathrm{T}}$ differentiate it from other members of the genus Kocuria at the phenotypic level (Table 1).

On the basis of its phenotypic and genotypic properties, it is proposed that strain YIM $70003^{\mathrm{T}}$ represents a novel species of the genus Kocuria, for which the name Kocuria aegyptia sp. nov. is proposed.

\section{Description of Kocuria aegyptia sp. nov.}

Kocuria aegyptia (ae.gyp'ti.a. L. fem. adj. aegyptia from Egypt, referring to the country of isolation of the type strain).

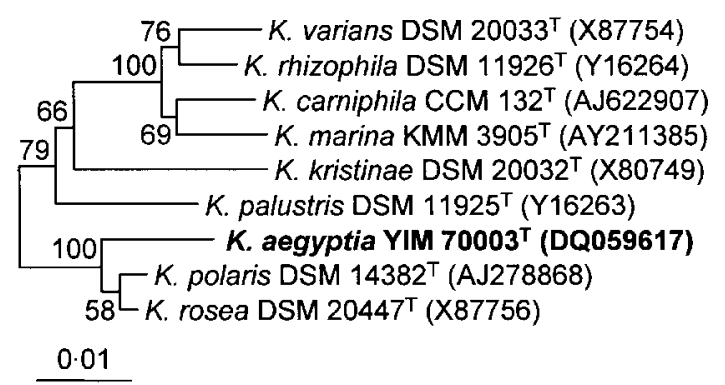

Fig. 1. Phylogenetic dendrogram obtained by distance matrix analysis of 16S rRNA gene sequences, showing the position of strain YIM $70003^{\top}$ among its phylogenetic neighbours. Numbers on branch nodes are bootstrap percentages (1000 resamplings); only values over $50 \%$ are shown. The sequence of Streptomyces megasporus DSM $41476^{\top}$ (Z68100) was used as a root (not shown). Bar, $1 \%$ sequence divergence. 
Cells are Gram-positive, coccoid, occur in pairs, tetrads or clusters, are non-motile and do not form endospores. Colonies are pink, circular, opaque and approximately $2 \mathrm{~mm}$ in diameter. Cannot grow in ISP 2 medium without salt, but can grow in ISP 2 medium containing $1-5 \% \mathrm{NaCl}$, $1-10 \% \mathrm{KCl}, 1-5 \% \mathrm{MgCl}_{2} \cdot 6 \mathrm{H}_{2} \mathrm{O}$ or $1-5 \% \mathrm{CaCl}_{2}$; optimum growth occurs at $3 \%$, but at $5 \%$ in the case of $\mathrm{KCl}$. The temperature range for growth is $20-40{ }^{\circ} \mathrm{C}$, with optimum growth occurring at $28^{\circ} \mathrm{C}$. The $\mathrm{pH}$ range for growth is $5 \cdot 0$ $12 \cdot 0$, with optimum growth occurring between at $\mathrm{pH} 10 \cdot 0$ $10 \cdot 5$. The oxidase test with tetramethyl- $p$-phenylenediamine is negative. Negative for urease, $\mathrm{N}$-acetylglucosaminidase, L-aspartic arylamidase, $\beta$-galactosidase, $\alpha$-galactosidase, $\alpha$-maltosidase, $\beta$-glucuronidase, Tweens 20 and 80 , esterase, tyrosinase, in methyl red and Voges-Proskauer tests, for melanin, indole and $\mathrm{H}_{2} \mathrm{~S}$ production, nitrate reduction, gelatin liquefaction, milk peptonization and coagulation and for starch hydrolysis; the catalase reaction is positive. Produces ornithine decarboxylase, arginine dihydrolase, lysine decarboxylase, lipase, $\beta$-glucosidase and ammonia. Maltose, D-glucose, D-cellobiose, D-trehalose, D-sorbitol, D-fructose, D-mannose and dextrin can each be utilized as a sole carbon source; acid is produced only from $\mathrm{D}$-fructose. The peptidoglycan type is Lys- $\mathrm{Ala}_{3}$, variation $\mathrm{A} 3 \alpha$. The cellwall sugars consist mainly of galactose and minor amounts of glucose. The phospholipids are phosphatidylglycerol and diphosphatidylglycerol. The predominant menaquinones are MK- $8\left(\mathrm{H}_{2}\right)$ and MK- $9\left(\mathrm{H}_{2}\right)$. The major cellular fatty acids are ai- $\mathrm{C}_{15: 0}(55 \cdot 3 \%)$ and $\mathrm{i}-\mathrm{C}_{15: 0}(20 \cdot 4 \%)$. The $\mathrm{G}+\mathrm{C}$ content of the DNA is $73.0 \mathrm{~mol} \%$.

The type strain is YIM $70003^{\mathrm{T}}\left(=\right.$ CCTCC AA203006 ${ }^{\mathrm{T}}=\mathrm{CIP}$ $\left.107966^{\mathrm{T}}=\mathrm{KCTC} 19010^{\mathrm{T}}=\mathrm{DSM} 17006^{\mathrm{T}}\right)$ and was isolated from a saline, alkaline, desert-soil sample collected from Egypt.

\section{Acknowledgements}

The authors are grateful to Professor Reiner M. Kroppenstedt and Dr R. Pukall for kindly providing type strains. This research was supported by the National Basic Research Program of China (project no. 2004CB719601), the National Natural Science Foundation of China (project no. 30270004) and the Yunnan Provincial Natural Science Foundation (project no. 2004 C0002Q). W.-J.L. was also supported by the Program for New Century Excellent Talent in University (NCET).

\section{References}

Boháček, J., Kocur, M. \& Martinec, T. (1969). Deoxyribonucleic acid base composition of Micrococcus roseus. Antonie van Leeuwenhoek 35, 185-188.

Cerny, G. (1978). Studies on aminopeptidase for the distinction of Gram-negative from Gram-positive bacteria. Eur J Appl Microbiol Biotechnol 5, 113-122.

De Ley, J., Cattoir, H. \& Reynaerts, A. (1970). The quantitative measurement of DNA hybridization from renaturation rates. Eur J Biochem 12, 133-142.

Felsenstein, J. (1985). Confidence limits on phylogenies: an approach using the bootstrap. Evolution 39, 783-789.
Gonzalez, C., Gutierrez, C. \& Ramirez, C. (1978). Halobacterium vallismortis sp. nov., an amylolytic and carbohydrate-metabolizing, extremely halophilic bacterium. Can J Microbiol 24, 710-715.

Horikoshi, K. \& Grant, W. D. (editors) (1998). Extremophiles: Microbial Life in Extreme Environments. New York: Wiley.

Huß, V. A. R., Festl, H. \& Schleifer, K.-H. (1983). Studies on the spectrophotometric determination of DNA hybridization from renaturation rates. Syst Appl Microbiol 4, 184-192.

Jahnke, K. D. (1992). BASIC computer program for evaluation of spectroscopic DNA renaturation data from Gilford System 2600 spectrophotometer on a PC/XT/AT type personal computer. J Microbiol Methods 15, 61-73.

Kelly, K. L. (1964). Inter-Society Color Council - National Bureau of Standards Color-name Charts Illustrated with Centroid Colors. Washington, DC: US Government Printing Office.

Kim, S. B., Nedashkovskaya, O. I., Mikhailov, V. V., Han, S. K., Kim, K. O., Rhee, M. S. \& Bae, K. S. (2004). Kocuria marina sp. nov., a novel actinobacterium isolated from marine sediment. Int J Syst Evol Microbiol 54, 1617-1620.

Kimura, M. (1980). A simple method for estimating evolutionary rates of base substitutions through comparative studies of nucleotide sequence. J Mol Evol 16, 111-120.

Kimura, M. (1983). The Neutral Theory of Molecular Evolution. Cambridge: Cambridge University Press.

Kloos, W. E., Tornabene, T. G. \& Schleifer, K. H. (1974). Isolation and characterization of micrococci from human skin, including two new species: Micrococcus lylae and Micrococcus kristinae. Int J Syst Bacteriol 24, 79-101.

Kocur, M., Bergan, T. \& Mortensen, N. (1971). DNA base composition of Gram-positive cocci. J Gen Microbiol 69, 167-183.

Kovács, G., Burghardt, J., Pradella, S., Schumann, P., Stackebrandt, E. \& Marialigeti, K. (1999). Kocuria palustris sp. nov. and Kocuria rhizophila sp. nov., isolated from the rhizoplane of the narrow-leaved cattail (Typha angustifolia). Int J Syst Bacteriol 49, 167-173.

Kumar, S., Tamura, K., Jakobsen, I.-B. \& Nei, M. (2001). MEGA2: molecular evolutionary genetics analysis software. Bioinformatics 17, 1244-1245.

Li, W.-J., Chen, H.-H., Xu, P., Zhang, Y.-Q., Schumann, P., Tang, S.-K., Xu, L.-H. \& Jiang, C.-L. (2004). Yania halotolerans gen. nov., sp. nov., a novel member of the suborder Micrococcineae from saline soil in China. Int J Syst Evol Microbiol 54, 525-531.

Marmur, J. \& Doty, P. (1962). Determination of the base composition of deoxyribonucleic acid from its thermal denaturation temperature. J Mol Biol 5, 109-118.

Reddy, G. S. N., Prakash, J. S. S., Prabahar, V., Matsumoto, G. I., Stackebrandt, E. \& Shivaji, S. (2003). Kocuria polaris sp. nov., an orange-pigmented psychrophilic bacterium isolated from an Antarctic cyanobacterial mat sample. Int J Syst Evol Microbiol 53, 183-187.

Saitou, N. \& Nei, M. (1987). The neighbor-joining method: a new method for reconstructing phylogenetic trees. Mol Biol Evol 4, 406-425.

Stackebrandt, E., Koch, C., Gvozdiak, O. \& Schumann, P. (1995). Taxonomic dissection of the genus Micrococcus: Kocuria gen. nov., Nesterenkonia gen. nov., Kytococcus gen. nov., Dermacoccus gen. nov., and Micrococcus Cohn 1872 gen. emend. Int J Syst Bacteriol 45, 682-692.

Thompson, J. D., Gibson, T. J., Plewniak, F., Jeanmougin, F. \& Higgins, D. G. (1997). The CLUSTAL_X windows interface: flexible strategies for multiple sequence alignment aided by quality analysis tools. Nucleic Acids Res 25, 4876-4882. 
Tvrzová, L., Schumann, P., Sedláček, I., Páčová, Z., Spröer, C., Verbarg, S. \& Kroppenstedt, R. M. (2005). Reclassification of strain CCM 132, previously classified as Kocuria varians, as Kocuria carniphila sp. nov. Int J Syst Evol Microbiol 55, 139-142.

Wayne, L. G., Brenner, D. J., Colwell, R. R. \& 9 other authors

(1987). International Committee on Systematic Bacteriology. Report of the ad hoc committee on reconciliation of approaches to bacterial systematics. Int J Syst Bacteriol 37, 463-464.
Xu, P., Li, W. J., Xu, L. H. \& Jiang, C. L. (2003). A microwave-based method for genomic DNA extraction from actinomycetes. Microbiology 30, 82-84 (in Chinese).

Xu, P., Li, W.-J., Tang, S.-K., Zhang, Y.-Q., Chen, G.-Z., Chen, H.-H., Xu, L.-H. \& Jiang, C.-L. (2005). Naxibacter alkalitolerans gen. nov., sp. nov., a novel member of the family 'Oxalobacteraceae' isolated from China. Int J Syst Evol Microbiol 55, $1149-1153$. 